tiglobalizaciju etnocentrizam i ksenofobija, odnosno isključivanje. Globalizacija, kao izraz modernizacije i kao integracija svijeta, na razini lokalnih društava i nacionalnih država generira antiglobalizacijska djelovanja u obliku desnih radikalnih stranaka i pokreta s markerima kao što su antiimigracija, suprotstavljanje multikulturalizmu, ksenofobija i islamofobija. Svjedoci smo da se danas pojavljuju nove desnice $\mathrm{u} t \mathrm{zv}$. visokorazvijenim zemljama: Njemačkoj, Francuskoj, Nizozemskoj, Austriji, Danskoj, Velikoj Britaniji, Svedskoj i Italiji.
$\mathrm{Na}$ eventualno pitanje čitatelja kako u današnje doba ublažiti pojavu neprijateljstva prema strancima uzrokovanu etnocentrizmom autor daje jedan od mogućih odgovora: kontaktima unutarnjih i vanjskih skupina te integracijom i akulturacijom - naravno, sve to pod pretpostavkom tolerancije.

Dinka Pasini

Filozofski fakultet Sveučilišta u Zagrebu, Zagreb
Edvin Pezo

\section{Zwangsmigration in Friedenszeiten? Jugoslawische Migrationspolitik und die Auswanderung von Muslimen in die Türkei (1918 bis 1966)}

München: Oldenbourg Verlag, 2013, 374 str. (Südosteuropäische Arbeiten, 146)

DOI: 10.11567/met.29.3.8

U odgovoru na još uvijek polemičko pitanje pripada li islam povijesnom naslijeđu Europe njemački povjesničar Edvin Pezo u uvodu svoje iznimne studije Zwangsmigration in Friedenszeiten? Jugoslawische Migrationspolitik und die Auswanderung von Muslimen in die Türkei (1918 bis 1966) podsjeća na činjenicu da je jugoistok europskog kontinenta od 14. stoljeća bio dio Osmanlijskoga Carstva te je time islam zauvijek ostavio traga u Europi i udomio značajnu muslimansku populaciju. I dok je, s jedne strane, osmanlijsko povlačenje s jugoistoka Europe bilo u pravilu popraćeno značajnim iseljavanjem Turaka i drugih muslimana, s druge strane, unatoč stalnim ili povremenim emigracijskim valovima, muslimanske su zajednice ostale do danas integralni dio regije. Tako znatan broj Turaka živi u južnim i sjeveroistočnim dijelovima Bugarske te $\mathrm{u}$ krajevima koji su činili bivšu Jugoslaviju, najviše u Makedoniji. Osim Turaka i Albanci tvore značajnu skupinu muslimana kao i regionalne koncentracije slavenskog stanovništva koje se islamiziralo, najbrojniji su u Bosni i Hercegovini i u Sandžaku, a brojni su i u Bugarskoj i Grčkoj. I, konačno, značajni postotak Roma, raširen po svim zemljama jugoistočne Europe, čine također muslimani. Činjenica da su spomenute države, s izuzetkom Albanije, u osnovi kršćanske činilo je (čini) položaj muslimanskih zajednica unutar njih posebno problematičnim. Ideologija koja tumači da je država prirodni teritorij jedne dominantne etničke/ nacionalne skupine znači u praksi da politička i ekonomska moć pripada samo većinskom narodu, s minimal- 
nim sudjelovanjem manjina u podjeli vlasti. Iznimka od toga centralističkog modela bila je bivša Jugoslavija, premda je i tu bio zamjetan zaokret od prvotne stanovite centralizacije vlasti prema decentralizaciji nakon šezdesetih godina 20. stoljeća.

Povijest Jugoslavije velikim je dijelom i povijest migracija. Naime, kako ističe autor, i 1918. osnovana Kraljevina kao i u Drugome svjetskom ratu stvorena socijalistička Jugoslavija na svojem su se teritoriju suočile s etničkim skupinama koje su u većini smatrale neželjenim ostatkom starih sustava vlasti. Osim na Nijemce i Mađare u Vojvodini, takav se stav posebice odnosio na muslimane (Albance, Bošnjake i Turke) u južnim dijelovima zemlje. Muslimane je još dvadesetih godina 20. stoljeća kršćanska većina prepoznala kao neželjeni ostatak osmanlijske prošlosti te se stoga veliki broj njih iselio $\mathrm{u}$ Tursku nakon oba svjetska rata.

Na osnovi podrobnih analiza i usporedbi jugoslavenskih i albanskih izvora, kao i vrlo bogate literature, s osobitom naglaskom na Kosovo, Makedoniju i Sandžak, autor upozorava na očite kontinuitete, ali i značajne diskontinuitete $\mathrm{u}$ migracijskim politikama prve i druge Jugoslavije.

Do danas politički konotirano pitanje o »prisilnoj migraciji muslimana $u$ razdobljima mira « nailazi u ovoj knjizi prvi put na obuhvatan, uravnotežen odgovor. Edvin Pezo izdvaja posebno dva razdoblja u kojima dolazi do izražaja prisilna migracija: neposredno nakon 1918. u smjeru Albanije, te $\mathrm{u}$ drugoj polovini tridesetih godina prema Turskoj. U pogledu iseljavanja muslimana tijekom pedesetih godina, detaljna analiza ukupnosti emigracij- skih motiva nikako se ne može svesti na politiku prisilne migracije, zaključuje autor.

Autorov središnji problemski i istraživački interes tiče se državnih strategija čiji je cilj bio reguliranje migracijskih kretanja $\mathrm{u}$ razdobljima »mira« između dva rata te tijekom prva dva desetljeća nakon Drugog svjetskog rata, pri čemu je fokus na iseljavanju muslimanskog stanovništva iz južnih dijelova Jugoslavije u Tursku.

Kako autor uvodno objašnjava, religijska pripadnost emigranata islamu služi u radu kao zajednička poveznica, dok kolektivni pojam »muslimani « obuhvaća veće i manje skupine koje se jezično i sociokulturološki međusobno razlikuju. Tako se etnički razlikuju Albanci, Bosanci, Turci, Pomaki, Torbeši i Romi, no neujednačena terminologija u jugoslavenskim aktima otežava etničko smještanje emigranata i stoga se u knjizi primarno upotrebljava pojam »muslimani «.

Proglašenjem Kraljevine Jugoslavije 1918. nastala je politička zajednica u kojoj je etnička heterogenost bila pravilo, a ne izuzetak. Osim službeno proklamiranih naroda Srba, Hrvata i Slovenaca država je uključivala brojne etničke grupe koje zbog svojih jezičnih, vjerskih, običajnih ili drugih obilježja nisu pripadale južnoslavenskim »državotvornim narodima«. To se prije svega odnosilo na neslavenske skupine koje su u većem broju nastanjivale južne krajeve zemlje, i Vojvodinu. Kako bi se različiti i ponegdje međusobno konkurentski procesi izgradnje države i nacije približili zamišljenom idealu, državni su se akteri služili različitim strategijama. Migracijska politika bila je u tom procesu jed- 
na od značajnih sastavnica društvenoga i političkog djelovanja u kojima su dolazile do izražaja naglašene nacionalno-političke i ideološke zamisli.

Nastojanja državnih vlasti da usmjeruju i reguliraju migracijske tokove čine bit državne društvene politike i stoga migracijska politika mnogo govori o stanju nekog društva. To je prije svega slučaj kada se pojedince ili skupine kategorizira prema njihovim etničkim, religijskim, socijalnim ili imovinskim obilježjima - od prihvatljivih do neželjenih - osobito kada se time trebaju očuvati (zamišljeni) državni nacionalni interesi.

Dok je u slučaju ekonomske migracije južnoslavenskog stanovništva na Zapad država u pravilu zauzimala zaštitnički stav, dotle se prema emigraciji onih koji se nisu mogli ubrojiti među južnoslavenske narode, poput Turaka i Albanaca, držala distancirano. Objema tim skupinama Zakonom o državljanstvu 1928. država otvara vrata trajnom iseljavanju. Neslavenskim muslimanima država je i 1953., neslužbenim dogovorom s Turskom, ponudila opcije: odlazak u Tursku ili ostanak u Jugoslaviji. Osobe koje su prihvatile prvu opciju ispisane su iz jugoslavenskog državljanstva. Sporazum 1953. između ministarstava vanjskih poslova Jugoslavije i Turske pokrenuo je po broju i posljedicama najznačajnije iseljavanje $u$ povijesti Jugoslavije u smjeru Turske. Jugoslavenske su vlasti tumačile iseljavanje i spajanje obitelji kao »akt humanosti«, dok se muslimansko stanovništvo, osobito ono s albanske strane, osjećalo ugroženo. No, kako ističe autor, Sporazum iz 1953. imao je posve drugačiji karakter od Sporazuma iz 1938. Suprotno od razdoblja između dva rata, kada je
Beograd imao velikog udjela u potpisivanju konvencije s Turskom o iseljavanju, početkom pedesetih inicijativu je pokrenula Turska. I dok su jugoslavenske vlasti između dva svjetska rata slijedile etnopolitičke ciljeve u pogledu Albanaca, smatrajući ih »anacionalnim elementom», to pedesetih godina nije bio slučaj.

Značenje Turske u procesu iseljavanja ne može se ni u kojem slučaju precijeniti, upozorava autor, jer Turska je otvarala vrata imigrantima ili ih je zatvarala. Cijela povijest iseljavanja u Tursku bez uvažavanja sociopolitičkoga i gospodarskoga konteksta te zemlje kao cilja emigracije nije zamisliva. Karakteristično za modernu nacionalnu državu, Turska je u okvirima svoje imigracijske politike, slično kao i Jugoslavija, djelovala u interesu pojedinaca i skupina koji su bili najbliži njezinoj koncepciji nacije države. To su prije svega bili etnički Turci, a potom i svi drugi koji su mogli dokazati bliskost $\mathrm{s}$ turskim jezikom odnosno s njezinom kulturom. Pritom se Turska pokazala otvorenijom prema slavenskim muslimanima nego prema albanskima.

No na pitanje o stvarnim razlozima iseljavanja teško je odgovoriti, zaključuje Pezo. Doduše očekivanje da će emigracijom u Tursku ostvariti bolju budućnost bilo je u pravilu zajedničko većini muslimana. Dok su između dva rata primjenjivani razni oblici prisile, prije svega državna praksa kolonizacije južnih krajeva zemlje te iskustvo manje ili više otvorenog nasilja, dakle negativna percepcija državne vlasti, za pedesete godine može se donekle govoriti o zadiranju države u muslimanski svijet kao takav. Jer nova se Jugoslavija svojom socijali- 
stičkom slikom svijeta, svojom politikom spram religija općenito i potporom modernizacijskim procesima našla nasuprot svijetu islama. Muslimani su novi društveno-ekonomski poredak i svjetonazor doživljavali kao "protiv nas «, već i na osnovi negativnih iskustava s jugoslavenskom državom između dva svjetska rata.

Autor upućuje na blisku spregu migracija, nacionalne države i manjina, odnosno politike države naspram nacionalnih manjina. Ta se sprega pokazala osobito snažnom unutar okvira državne "reemigracijske politike« između dva rata; bilo je naime očito kako se predodžbe o naciji državi i percepcija manjina odražavaju na migracijsku politiku. U nastojanju da se onemogući povratak Albanaca i Turaka u Kraljevinu Jugoslaviju sustavno su generirani strahovi i otpor spram pripadnika tih dvaju naroda kao onih koji nisu sposobni za integraciju pa stoga ni poželjni.

Povijest iseljavanja iz Jugoslavije u Tursku sadržava elemente koji se mogu nazvati prisilnim migracijskim mjerama. To prije svega vrijedi za drugu polovinu tridesetih godina 20. stoljeća, u situaciji u kojoj se odnos prema državi u cijelosti iznova propituje, dok Italija svojom ekspanzionističkom politikom prema Balkanu ugrožava srpske geopolitičke interese na jugu zemlje. U srpskom se razumijevanju nacije javljaju elementi isključivanja manjina i nasilja spram njih. Iznova se preispituju politika iseljavanja u Tursku te kolonizacija juga Srbije. Istovremeno stižu signali iz Turske $u$ pogledu mogućeg dogovora $u$ vezi s emigriranjem. Kako se albanska manjina u svojoj ukupnosti percipira anacionalnom i nelojalnom, prije sve- ga ona postaje ciljem politike iseljavanja putem raznih oblika prinude. Nasilje spram Albanaca povezuje se prije svega s »erom Stojadinovića«, s vremenom u kojem se prema neslavenskim narodima južne Srbije, ponajprije prema albanskome, prakticirala otvorena represija s namjerom postizanja njihova trajnog preseljenja $u$ Tursku.

No, upozorava autor, iseljavanje muslimana u Tursku povuklo je za sobom brojne posljedice za obje strane. Emigracijom pogođene regije Jugoslavije izmijenile su se kulturološki, ali i gospodarski, ali i za zemlju primitka, Tursku, veliki priljev imigranata bio je nemali izazov. Emigracija je ostavila u naslijeđe i druge probleme jer je državna politika iseljavanja opteretila međuetničke odnose. Prije svega, politika provođena između dva rata pokazala se teškom hipotekom za budući odnos Beograda i albanske manjinske populacije Jugoslavije.

Istraživanje migracijskih politika u prvoj i drugoj Jugoslaviji, uključujući i Tursku, u svojoj se ukupnosti pokazalo opravdanim i plodnim. Sličnosti, no prije svega razlike postale su jasnije; usporedba je pomogla da se istaknu specifičnosti, ali i utvrdi stanovita kontinuiranost. S jedne strane, iseljavanje u Tursku značajno se razlikovalo od emigracije na Zapad, ne toliko kroz nacionalno-političke konotacije, koje su bile prisutne u oba slučaja, koliko u obliku oštrije državne intervencije u pogledu emigracije muslimana, naglašava Pezo. Nadalje, između dva rata proces iseljavanja bio je podređen prije svega etnopolitičkim interesima koji su 1938. rezultirali međudržavnom konvencijom. Nakon 1945. iseljavanje se odvijalo pod aspektom mo- 
dernizacije, dakle ne u okviru ciljane emigracijske politike. Ipak, ono se i tu pokazalo indikatorom percepcije muslimana kroz većinsko južnoslavensko društvo.

Knjiga se sastoji od opširnog »Uvoda« (»Einführung«), koji dotiče pitanja nacije, nacionalizma, odnosa većine te etnički i kulturno nesrodnih manjina $\mathrm{u}$ novostvorenoj političkoj zajednici, uključuje objašnjenje termina i metodologije, stanje dosadašnjih istraživanja kao i pitanje izvora, naime dostupnosti arhiva u pojedinim zemljama sljednicama Jugoslavije, ali i onih u Tirani i Ankari. Slijedi sedam poglavlja, od kojih se svako sastoji od više ulomaka, zaključak te dvadeset pet stranica popisa upotrijebljene arhivske i druge dokumentacijske građe i citirane sekundarne literature. $U$ knjizi je i niz usporednih tabličnih i grafičkih prikaza. Sve to govori o temeljitosti ove studije i količini podataka koje nudi.

Prvo poglavlje »Statistische Annährung « analizira i uspoređuje statističke izvore za razdoblje između dva rata te nakon 1945., koji se odnose na kvantitativni aspekt iseljavanja u Tursku. Drugo poglavlje »Zielvorstellungen und Leitlinien staatlicher Emigrations- und Remigrationspolitik « istražuje migracijsku politiku prije Drugoga svjetskog rata, migracijsku politiku Jugoslavije nakon 1945. te zakonsku regulativu u pogledu državljanstva kao instrumenta reguliranja iseljavanja u Tursku. Ovdje je riječ i o jugoslavenskoj »reemigracijskoj politici« prema jugoslavenskim muslimanima iz Turske (do 1941.), o etničkoj kategorizaciji u vremenu diktature te o politici reemigracije sa socijalističkim predznakom.
Poglavlje »Zum Auswanderungsverhalten: In- und ausländische Einflussfaktoren« bavi se migracijskim politikama Turske i Albanije, utjecajem Albanije na iseljavanje $u$ Tursku, unutardržavnim čimbenicima emigracije između dva rata te migracijskom dinamikom pedesetih godina. U poglavlju »'Staatlich vereinbart' - Jugoslawisch-türkische Abkommen zur Aussiedlung nichtslawischer Muslime « autor istražuje društveno-politički kontekst koji dovodi do potpisivanja jugoslavensko-turske Konvencije 1938., ulogu Milana Stojadinovića, neuspjeh Konvencije te formiranje Sporazuma o iseljavanju između Jugoslavije i Turske 1953., takozvani Gentlemen's Agreement. U petom poglavlju »Innerstaatliche Migrationspolitik. Siedlungs- und agrarpolitische Aspekte« obrađuje se pitanje provedbe agrarne reforme i politike kolonizacije $u$ obje Jugoslavije između dva rata te $\mathrm{u}$ socijalističkoj Jugoslaviji, s fokusom na južnu Srbiju. Predzadnje poglavlje »Gewalterfahrung und Vertreibungsdiskurse « istražuje mjere ciljanog državnog nasilja i državne represije u svrhu poticanja na iseljavanje, posebice albanskih žitelja, tijekom tri ključna razdoblja: 1918. - 1925., 1935. - 1940. i 1950. - 1956./57.

U zadnjemu poglavlju »Die Türkei-Emigration der 1950er Jahre. Folgewirkungen und die Positionen des Bundes der Kommunisten« autor istražuje stavove jugoslavenskih komunista prema iseljavanju, »zone« iseljavanja, pitanje načina ophođenja sa slavenskim i albanskim emigrantima te posljedice masovne emigracije u Tursku na razvoj pojedinih područja Makedonije. 
U zaključnom dijelu »Schlusswort « sažimlje svoja saznanja o procesu formiranja nacija i položaja etničkih odnosno nacionalnih manjina $\mathrm{u}$ nacijidržavi, čiju se prisutnost nastojalo, pa i prisilnim mjerama iseljavanja, smanjiti ako se nisu uklapale u vladajuće nacionalne intencije.

Ova bi studija, zaključuje autor, trebala potaknuti na nova istraživanja. Jer ma koliko se u radu nastojalo ući u višestruku slojevitost procesa iseljavanja muslimanskog stanovništva u Tursku u navedenim razdobljima, ostaje još mnogo nepoznatoga. Prema autorovu mišljenju, sljedeći važni moment uključivao bi sustavno istraživanje samih emigranata, njihovih potomaka i svjedokâ vremena, odnosno istraživanje posljedica jugoslavenskih migra- cijskih politika na ljude koji su ih iskusili, kako bi se dobila izoštrenija slika međuodnosa države i muslimanskih iseljenika.

Knjiga Zwangsmigration in Friedenszeiten? Jugoslawische Migrationspolitik und die Auswanderung von Muslimen in die Türkei (1918 bis 1966) vrlo je temeljit znanstveni pothvat koji daje kompleksan uvid u uzroke, tijek, pa i posljedice odnosa jugoslavenskih migracijskih politika i muslimanskog stanovništva u obje Jugoslavije. Premda je prije svega namijenjena povjesničarima i stručnjacima za migracije i međunarodne odnose u jugoistočnoj Europi, može biti korisno štivo i široj znanstvenoj i stručnoj javnosti.

Ružica Čičak-Chand

Zagreb 